\title{
INFLUENCE OF MACROECONOMIC FACTORS ON STOCK PRICES IN POLAND - CROSS SECTION AND TIME SERIES ANALYSIS
}

\author{
Tomasz Schabek ${ }^{1}$, Nijolė Maknickiene் ${ }^{2}$ \\ ${ }^{1}$ Faculty of Economics and Sociology, University of Lodz, POW 3/5 90-255, Lodz, Poland \\ ${ }^{2}$ Department of Financial Engineering,Gediminas Technical University, Sauletekio 11, Vilnius, Lithuania \\ E-mails: ${ }^{1}$ tomasz.schabek@uni.lodz.pl; ${ }^{2 n i j o l e . m a k n i c k i e n e @ v g t u . l t ~(c o r r e s p o n d i n g ~ a u t h o r) ~}$
}

\begin{abstract}
The purpose of the study is to determine if the macroeconomic factors influence rates of returns from broad index of stocks in Poland. The study investigates stability of relation between macroeconomic and stock market variables in short and long time period. After running time series regressions we check if selected macro variables are still significant in cross-section of stock returns including control variables like price to book value, capitalization and momentum. The study is based on large sample of individual rates of returns and macroeconomic variables describing real sphere of the economy. Mine findings suggest that the short and long term relation is statistically and economically significant although not stable in the both analysed time horizons. Macroeconomic beta parameter (sensitivity to macro variables measure) is not significant in cross-sectional test proving that traditionally accepted variables (in our study only price to book-value and momentum) still better explain the expected returns.
\end{abstract}

Keywords: macroeconomic factors, cross-section, Polish stock market, expected returns.

JEL Classification: G12, G10.

\section{Introduction}

Main goal of the research is to explore relations between macroeconomic variables and stock market returns in Poland. Analysis of macroeconomic variables related to real part of economy (understood as opposite to monetary part) that potencially describe broad stock market index in Poland (WIG index) is main part of the study. Our focus is only on real macroeconomic factors similarly to Fama (1990), Schwert (1990) and Peiro (2016). The reasoning during the research was following. If some of real macroeconomic variables impact stock market measured by rates of returns of broad market (WIG index) therefore these variables should influence majority of the WIG index constituents, individual companies. This implies that stocks rates of return sensitivity measure constructed basing on these macroeconomic variables could potentially explain cross-section of stock returns and be useful and informative in the process of asset allocation. This sensitivity measure is analogous to beta in CAPM model. The analysis was conducted in two spheres: studying relation between variables across time and later across companies. Time series based analysis allows us to test the hypothesis about existence (and potential changes in time) of short and long term relationship between macroeconomic variables and stock returns. Thanks to this part of the research variables that shape the process of stock returns generation can be identified. In the study the economically applicable results are our main concern, therefore we did not use leads but rather lags in macroeconomic variables during the analysis. In later part of the study transaction cost and risk to return characteristics of simple strategy was introduced, to ensure that results are economically meaningful for investors. Cross-sectional analysis from the other hand allows to verify hypothesis stating that stocks characterized by higher sensitivity (i.e. coefficient from time series based regressions) to the changes of macroeconomic variable(s) have higher cross-sectional results, as they are more risky.

The remainder of the paper is organized as follows: in the next section up to date literature was introduced; section 2, contains description of the variables and the method used; section 3, includes presentation and discussion of the main results; the last section contains conclusions. 


\section{Previous studies}

Many researchers tries to discover candidates influencing stock market returns in the set of macroeconomic variables. Such approach follows the common sense that cash flows generated by companies depend on economic performance of the country. Macroeconomic variables are also in the center of empirical verification of arbitrage pricing theory developed by Ross (1976). Although such variables are subject of many studies in United States (see: Bianchi, Guidolin, \& Ravazzolo, 2017; Chan, Karcesky, \& Lakonishok, 1998; Chen, Roll, \& Ross, 1986; Fama, 1990; Maio \& Philip, 2015) and European developed countries (Canova \& De Nicolo, 1995; Errunza \& Hogan, 1998; Panetta, 2002; Peiro, 2016; Rapach, Wohar, $\&$ Rangvid, 2005). There is much less research related to emerging markets (South Asian market: Khan, Tantisantiwong, Fifield, and Power (2015); Lithuania: Jurksas and Paskevicius, (2017); Dzikevičius and Šarand (2016); group of emerging markets: Narayan, K. P., Narayan, S., and Thuraisamy (2014); Visegrad Group: Pražák and Stavárek (2017)).

Results of studies concerning Central European markets support the thesis of relevant and significant impact of macroeconomic factors on stock returns in regional economies. Tvaronaviciene and Michailova (2006) prove relation between Vilnius stock market index and macroeconomic variables like: foreign direct investment, state budget revenue, state budget expenditure, gross domestic product, price index of consumer goods and services, money supply, average profitability of governmental bonds and inflation. Other research confirmed these conclusions also for sectoral indices on OMX Baltic securities market, Rudzkis and Valkaviciene (2014) and for short-time relationship - Pilinkus and Boguslauskas (2009). Autoregressive distributed lag model has been implemented in recent work of Jurksas and Paskevicius (2017) - authors found out that stock prices but also real estate prices are cointegrated with macroeconomic variables, although they suggest that implementing more frequently announced macroeconomic indicators and inclusion of analysis of relation between different assets return would improve the model.

Also regarding Polish market there are studies analyzing macroeconomic relations on stock market, but we did not find research involving cross-sectional test of macroeconomic variables impact on rates of returns on stock market. Samitas and Kenourgios (2007) found out that real variable (industrial production) is more relevant for stock market returns than nominal variable (interest rates). Horobet and Dumitrescu (2009) confirmed GDP as a factor (positively) affecting Polish stock market index but they find out also that the CPI and real interest rates has (negative) impact. Hsing and Hsieh (2012) report that industrial production and real GDP have positive association with market returns. Gurgul and Wójtowicz (2014) run their interesting analysis for intraday data and proved that foreign information (macroeconomic announcements) is transmitted into returns of main indices on Polish stock exchange. Meluzin, Zinecker, and Meluzinová (2015) studied influence of macroeconomic variables but in the Initial Public Offerings (IPO) and found that the interest rate (yields of Polish 10year government bonds) influence IPOs returns.

Ours study adds to the literature threefold, firstly tests of the findings are run in out of sample period, secondly long and short term period dependencies between macroeconomic variables and stock returns in Poland have been evaluated and finally we applied the sensitivity measure (coefficient) for testing the cross-sectional returns of individual stocks rates of return.

\section{Methods and data}

The main source of market data in our study (adjusted prices, capitalization and price to book value) was Reuters Datastream. The macroeconomic variables series comes from OECD database. Although Polish stock exchange started to operate in 1991 only after events like introducing continuous quotations (1997), electronic system of orders (2000) and start of future contract quotations (22.01.2001), this market becomes more liquid and developed, therefore first rate of return in the study is set-up for February 2001. The returns of the stocks that were part of WIG index at the end of 2017 are used, but excluding stocks for which Polish market was not the prime quoting market (foreign companies), companies with micro capitalization (below 20 millions of PLN) and companies with missing data. Monthly rates of returns are used, divided into the following categories:

- in the sample long term period: Feb 2001 - Aug 2013;

- in the sample short term period: Jul 2008 - Aug 2013;

- out of sample period: Sep 2013 - Dec 2017. 
Data used in the research are described in Table 1 . July 2008 was chosen because of one of the data availability (start of publication of PMI). All the variables have been tested for unit root and modified if needed. In the study we are interested in results possible to apply by investors therefore lags of two to six months were applied for macroeconomic variables (most of variables are published and available for investors two months after the period they correspond to). Lagged variables for the purpose of testing semi-strong efficient market hypothesis were used e.g. in the study of Hanousek and Filer (2000).

Table 1. Data description (source: created by authors)

\begin{tabular}{|c|l|l|l|}
\hline Symbol & \multicolumn{1}{|c|}{ Description } & Remarks & Source \\
\hline D_PMI & $\begin{array}{l}\text { Purchasing Man- } \\
\text { ager Index, index } \\
\text { of economic activ- } \\
\text { ity in the manu- } \\
\text { facturing sector } \\
\text { calculated by Mar- } \\
\text { kit Economics }\end{array}$ & $\begin{array}{l}\text { phange } \\
\text { period }\end{array}$ & $\begin{array}{l}\text { Ban- } \\
\text { kier.pl }\end{array}$ \\
\hline INDPRO & $\begin{array}{l}\text { Industrial produc- } \\
\text { tion, seasonally } \\
\text { adjusted }\end{array}$ & $\begin{array}{l}\text { Growth } \\
\text { previous } \\
\text { period }\end{array}$ & OECD \\
\hline RETA & $\begin{array}{l}\text { Total retail trade } \\
\text { (volume), season- } \\
\text { ally adjusted }\end{array}$ & $\begin{array}{l}\text { Growth } \\
\text { previous } \\
\text { period }\end{array}$ & OECD \\
\hline MANUF & $\begin{array}{l}\text { Total manufactur- } \\
\text { ing, seasonally } \\
\text { adjusted }\end{array}$ & $\begin{array}{l}\text { Growth } \\
\text { previous } \\
\text { period }\end{array}$ & OECD \\
\hline CONSTR & $\begin{array}{l}\text { Construction, sea- } \\
\text { sonally adjusted }\end{array}$ & $\begin{array}{l}\text { Growth } \\
\text { previous } \\
\text { period }\end{array}$ & OECD \\
\hline
\end{tabular}

In order to select variables that in the best way describe rates of returns of WIG index general-to-specific modelling (GETS) approach was implement, described e.g. in Hendry and Krolzig (2005). This method begins with the estimation of the general unrestricted model (GUM) including all explanatory variables. Then, variables that are statistically irrelevant are deleted consecutively till final specification is reached, without losing a lot of explanatory power. This procedure (automated within econometric packages) has been used mostly in empirical macroeconomic modelling but recently also in finance (e.g., Gnimassoun, 2015; Nell \& Thirlwall, 2018). GETS modelling was applied two times: for long term, in-the-sample period and short term, in- the-sample period, in order to compare results, check the robustness and gather more insights about analysed relation in short and long term.

After receiving final specification of the macroeconomic variables indicated by GETS process (see Table 2) the set of macroeconomic indicators in out of sample period was tested and checked if they are still relevant and importantly which set received (regressed on long period of data or short period) is more robust in out of sample data (see Table 3 ).

In next step of the study factor analysis (FA) was used. FA is variation of principal component analysis used by Çakmaklı and Dijk (2016), in order to reduce the set of significant variables to one factor. Models relying on factors extracted from broader set of variables are used also in works of Ludvigson and Ng (2007, 2009), Stock and Watson (2002) and earlier by Chen (1983) and Roll and Ross (1980). In this way we will not receive large set of variables that during the further econometric analysis can add additional parameter estimation uncertainty. Also interpretation of one coefficient is more straightforward for individual investors. Multiple explanatory variables are characterised by instability of as reported in Çakmaklı and Dijk (2016) and results of Rapach and Wohar (2006).

After employing FA two times: once for variables spanned on short term period and once for spanned on long term period we can test the robustness of both received during FA factors in out of the sample period. In this step of the analysis both factors were compared and one that was more robust in out of sample period was selected.

Equation (1) below presents our empirical model, which is estimated using the classical Fama and MacBeth (1973) (FM) procedure. The FM estimator is broadly used in the literature because it addresses the problem that the idiosyncratic errors might be highly correlated in each period caused by shocks that affect firms, which cause traditionally computed standard errors misleading. The first step in the FM procedure is to estimate a set of crosssectional regressions, in our case, 76 regressions using monthly data for 166 stocks. This procedure produce 76 sets of estimated coefficients. Later, these series were used to compute averages, standard deviations, and t-statistics, allowing us to test the statistical significance of each coefficient as in original FM study. Results of the FM procedure are presented in Table 5.

$$
\begin{aligned}
& r_{t}^{i}=\gamma_{0}+\gamma_{1} C A P_{t-1}^{i}+\gamma_{2} P B V_{t-1}^{i}+ \\
& \gamma_{3} M O M_{t-1}^{i}+\gamma_{4} \beta_{\text {macro },-1}^{1}+\varepsilon_{t}^{1} .
\end{aligned}
$$


Where: $r_{t}^{i}$ means the rate of return of stock $i$ month $t$, with $i=1, \ldots, 166$, and $t=1, \ldots, 76$; $C A P_{t-1}^{i}, P B V_{t-1}^{i}, M O M_{t-1}^{i}$, represent accordingly logarithm of capitalization, logarithm of price-tobook ratio, and momentum measures; $\beta_{\text {macro,t-1 }}^{i}$ means the sensitivity of the expected return of the $i$-th stock to changes in the selected earlier (in GETS procedure and later reduced in FA) macroeconomic factor, and $\varepsilon_{q}$ is the error term.

We used these standard control variables as suggested by results delivered by Banz (1981), Fama and French (1993) and Carhart (1997).

The variable $\beta_{\text {macro } t-1}^{i}$ in Eq. (1) needs be estimated using time-series regressions, therefore Eq. (2) was introduce below. Particularly, for each stock $i$ we estimate a set of 76 rolling window ordinary least squares (OLS) time-series regressions, with window length equal to 31 months (approximately the average length of one business cycle in Poland), where the dependent variable is the rate of return of the stock and the explanatory variable is selected earlier macroeconomic factor. Later the estimated $\beta_{\text {macro }}^{i}$ (sensitivity) was used as explanatory variable in Eq. (1).

$$
r_{t}^{1}=\alpha^{i}+\beta_{\text {macro }}^{i} F_{t}^{\text {macro }}+u_{t}^{i} .
$$

Where $F_{j, t}^{\text {macro }}$ is the macroeconomic factor acquired by employing first GETS and then FA analysis and selecting the most robust factor from two produced (one from short and one long term period data) $r_{t}^{i}$ is the rate of return of stock $i$ in month $t$, and $u_{t}^{i}$ is the idiosyncratic error term.

The first 31-month window spans from February 2009 to August 2011, the second goes from March 2009 to September 2011, and so on. Employing this algorithm, equation (2) was separately estimated for each of the 76 rolling 31-months window and each of the 166 stocks. Thus, the total number of estimates is therefore 166 times $76=12616$.

\section{Results}

After applying GETS method two variables (growth of industrial production and manufacturing lagged by 2 and 3 months accordingly) were received for the long term period, and three variables (growth of export and manufacturing lagged respectively by 6,2 and 3 months) for short term, see Table 3, below. All variables are statistically significant and suggesting that lagged production has positive impact on stock returns. The sign of coefficient related to export is confusing, firstly it suggests negative relation and secondly the six month lag is quite high, assuming that stock market should reflect present and future economic conditions.

Table 2. Specific model. In the sample GETS result for long and short term period (source: created by authors)

\begin{tabular}{|l|c|c|c|c|}
\hline Variable & Coefficient & Std. Error & t-value & t-prob \\
\hline \multicolumn{5}{|c|}{ Long term analysis } \\
\hline $\begin{array}{l}\text { INDPRO } \\
(-2)\end{array}$ & $0.008^{* * *}$ & 0.003 & 2.720 & 0.007 \\
\hline $\begin{array}{l}\text { MANUF } \\
(-3)\end{array}$ & $0.007^{* *}$ & 0.003 & 2.512 & 0.013 \\
\hline \multicolumn{5}{|c|}{ Short term analysis } \\
\hline EXPO(-6) & $-0.004^{* *}$ & 0.002 & -2.077 & 0.043 \\
\hline $\begin{array}{l}\text { MANUF } \\
(-2)\end{array}$ & $0.007^{*}$ & 0.004 & 1.860 & 0.069 \\
\hline $\begin{array}{l}\text { MANUF } \\
(-3)\end{array}$ & $0.013^{* * *}$ & 0.004 & 3.421 & 0.001 \\
\hline
\end{tabular}

Note: real growth rate (CPI adjusted) of WIG index is explained variable $*, * *$ and $* * *$ indicate statistical significance at the $10 \%, 5 \%$ and $1 \%$ levels, respectively.

Table 3. Out of sample regressions for long and short term period (source: created by authors)

\begin{tabular}{|c|c|c|c|c|}
\hline Variable & Coefficient & Std. Error & \multicolumn{2}{|c|}{ t-value t-prob } \\
\hline \multicolumn{5}{|c|}{ Long term analysis } \\
\hline $\begin{array}{l}\text { INDPRO } \\
(-2)\end{array}$ & 0.005 & 0.004 & 1.396 & 0.169 \\
\hline $\begin{array}{l}\text { MANUF } \\
(-3)\end{array}$ & $0.008^{* *}$ & 0.003 & 2.432 & 0.019 \\
\hline Const. & 0.000 & 0.007 & 0.038 & 0.970 \\
\hline \multicolumn{5}{|c|}{ Short term analysis } \\
\hline EXPO(-6) & 0.000 & 0.001 & 0.329 & 0.74 \\
\hline $\begin{array}{l}\text { MANUF } \\
(-2)\end{array}$ & 0.004 & 0.003 & 1.192 & 0.239 \\
\hline $\begin{array}{l}\text { MANUF } \\
(-3)\end{array}$ & $0.008^{* *}$ & 0.003 & 2.332 & 0.024 \\
\hline Const. & 0.000 & 0.007 & 0.047 & 0.963 \\
\hline
\end{tabular}

Note: real growth rate (CPI adjusted) of WIG index is explained variable $*, * *$ and $* * *$ indicate statistical significance at the $10 \%, 5 \%$ and $1 \%$ levels, respectively. The regressions specification has been tested for heteroscedasticity and autocorrelation (Lagrange multiplier test and LjungBox Q-statistics test, respectively) and adjusted in case of identifying heteroscedasticity (ARCH model applied) and/or autocorrelation (autoregressive term added).

Out of sample regressions results presented in Table 3 confirm that growth rate of manufacturing is most important in describing the real 
rates of return from WIG index - in both cases the influence is positive. After construction of factor analysis (FA) factors and evaluation of their significance results indicated that only the FA factor based on variables related to short term analysis specification is significant (see Table 4).

The FA was used to reduce number of variables only to one in order to limit possible problems in econometric analysis that could cause higher parameter estimation uncertainty, similar approach was used by Çakmaklı and Dijk (2016).

Table 4. Out of sample regressions for long and short term period for factors (source: created by authors)

\begin{tabular}{|l|c|c|c|c|}
\hline \multicolumn{1}{|c|}{ Variable } & $\begin{array}{c}\text { Coeffi- } \\
\text { cient }\end{array}$ & $\begin{array}{c}\text { Std. } \\
\text { Error }\end{array}$ & t-value & t-prob \\
\hline \multicolumn{5}{|c|}{ Long term analysis } \\
\hline $\begin{array}{l}\text { FA_LONG_ } \\
\text { TERM(-1) }\end{array}$ & -0.008 & 0.005 & -1.425 & 0.161 \\
\hline Const. & 0.006 & 0.006 & 0.926 & 0.359 \\
\hline \multicolumn{5}{|c|}{ Short term analysis } \\
\hline $\begin{array}{l}\text { FA_SHORT } \\
\text { TERM(-1) }\end{array}$ & $0.008^{*}$ & 0.005 & 1.743 & 0.088 \\
\hline Const. & 0.006 & 0.005 & 1.166 & 0.249 \\
\hline
\end{tabular}

Note: real growth rate (CPI adjusted) of WIG index is explained variable $* * *$ and $* * *$ indicate statistical significance at the $10 \%, 5 \%$ and $1 \%$ levels, respectively. The regressions specification has been tested for heteroscedasticity and autocorrelation (Lagrange multiplier test and LjungBox Q-statistics test, respectively) and adjusted in case of identifying heteroscedasticity (ARCH model applied) and/or autocorrelation (autoregressive term added).

Final step of our study involve estimation of Eq. (1). Results of the cross 76 sectional regressions (average coefficients and t-statistics related to each of them) are presented in Table 5, below. The dependent variable, monthly rate of return from individual stock was regressed on the set of control variables and the set of $\beta_{\text {macro } t-1}^{i}$ coefficients representing the sensitivity of individual stock rate of return on macroeconomic factor. The t-stat are presented in parentheses. We followed Fama and MacBeth (1973) method and computed each coefficient estimate as the mean from a set of OLS cross-sectional regression estimates, one for each of the 76 sample months; $t$-statistics, shown in parentheses, are given by $\frac{m}{s(m) / \sqrt{n}}$ where $m$ is the mean and $s(m)$ is the standard deviation of the $n$ cross-sectional coefficient estimates $(n=76)$.
Table 5. Results of estimation Eq. (1) (source: created by authors)

\begin{tabular}{|c|c|c|c|c|c|}
\hline $\begin{array}{c}\text { Mo- } \\
\text { del } \\
\text { spec- } \\
\text { ifica- } \\
\text { tion }\end{array}$ & Const. & CAP & MOM & P/BV & $\beta$ _macro \\
\hline \multirow{2}{*}{ (i) } & 0.008 & 0.000 & $0.110^{* *}$ & $-0.017 * * *$ & -0.090 \\
\cline { 2 - 6 } & $(0.999)$ & $(-0.162)$ & $(1.688)$ & $(-3.618)$ & $(-1.437)$ \\
\hline \multirow{2}{*}{ (ii) } & 0.008 & & $0.109 * *$ & $\begin{array}{c}-0.016 \\
* * *\end{array}$ & -0.049 \\
\cline { 2 - 2 } & $(1.452)$ & & $(1.692)$ & $(-3.875)$ & $(-0.764)$ \\
\hline \multirow{2}{*}{ (iii) } & 0.008 & & & $-0.013 * * *$ & -0.074 \\
\cline { 2 - 2 } \cline { 5 - 6 } & $(1.468)$ & & & $(-2.478)$ & $(-1.152)$ \\
\hline \multirow{2}{*}{ (iv) } & 0.007 & & & & -0.092 \\
\cline { 2 - 2 } \cline { 5 - 6 } & $(1.295)$ & & & & $(-1.479)$ \\
\hline
\end{tabular}

Note: Estimates of coefficients from cross-sectional regression (1).*,** and *** indicate statistical significance at the $10 \%, 5 \%$ and $1 \%$ levels, respectively.

Similarly to results reported by vast finance literature we observed that no other factors (in our case related to macroeconomic variables) provide significant explanatory power in cross-sectional regressions of stock market returns. Coefficients presented in Table 5 related to momentum are positive and significant indicating that stocks experiencing high positive momentum tend to have higher returns. These results are consistent with related research undertaken by other researchers. Similarly our results related to price to book $(\mathrm{P} / \mathrm{BV})$ value support previous studies and indicate that firms with high $\mathrm{P} / \mathrm{BV}$ characteristics bring lower expected results.

In order to check the economic usefulness of the results simple strategy was introduced: buy stock market index (WIG) when last month of value of FA factor has positive value and short sell the index when it's value is negative. We assumed similar to real on Polish stock market transaction costs $(0.19 \%)$. This strategy indicates that the $52 \%$ of all transactions were successful in the whole analyzed period and more importantly $58 \%$ in out of the sample period. This results are even more meaningful when compared the monthly average rate of return from the strategy, $0.63 \%$ versus $0.56 \%$ WIG return with even lower standard deviation in favor of the strategy $(5.16 \%$ vs $5.17 \%)$.

\section{Conclusions}

To our knowledge this study is the first that analyse cross-sectional relations between variables 
representing sensitivity to macroeconomic indicators and stock returns on Polish market. Our selection of macroeconomic variables is focused on real economy factors. Long (12 years) and short (5 years) time periods are used to identify market variables that influence broad market index. In order to do that general-to-specific modelling (GETS) was employed and after identification of macro variables we reduce (via factor analysis) the set of this variables to one factor. Using this factor in rolling 31-months window regressions set of coefficients (sensitivities) were estimated and later used in Fama and MacBeth (1973) procedure with standard group of control variables (capitalization, price to book value and momentum). Finally received cross-sectional coefficients were tested.

The conclusions from cross-sectional part of the analysis is strongly supportive for other researchers' results - we cannot reject the hypothesis that coefficients related to macroeconomic variables $\left(\beta_{\text {macro }}^{i}\right)$ in cross-section regressions are different from zero. Our $\beta_{\text {macro }}^{i}$ behaves similarly to classical beta of CAPM model - it describes very well the stocks returns across time but not as well across companies (insignificant CAPM beta is reported by many other researchers).

Time-series related part of our study has more promising results: one of analysed macroeconomic variable (rate of growth of manufacturing) is significant in out of sample period in long and short term period. Coefficient of lagged factor constructed via factor analysis from the set of macroeconomic variables is significantly different from zero in out of sample group not only in statistical sense but also economically in simple investing strategy, adjusted for transaction costs.

The implications of our study suggest that for asset allocation purposes (e.g. selecting firms to portfolio) investors should rely on price to book and momentum characteristics of the stocks rather macroeconomic factors. On the other hand macroeconomic factors could be good predictors of broad market returns across the time, even taking into account transaction costs. This proves that Polish stock market is not efficient in the sense of weak form of efficient market hypothesis, at least in the analysed period.

Interesting extensions that are left for further research include the empirical investigation of broader set of macroeconomic variables and other stock markets in Central Europe region. Also, test of stability of the relation between macroeconomic variables and stock markets in shorter but more numerous periods of time could shed light on this important for investors and researchers issues.

\section{References}

Banz, R. W. (1981). The relationship between return and market value of common stocks. Journal of Financial Economics, 9(1), 3-18. https://doi.org/10.1016/0304-405X(81)90018-0

Bianchi, D., Guidolin, G., \& Ravazzolo, F. (2017). Macroeconomic factors strike back: A Bayesian Change-Point Model of Time-Varying Risk Exposures and Premia in the U.S. Cross-Section. Journal of Business \& Economic Statistics, 35(1), 110-129. https://doi.org/10.1080/07350015.2015.1061436

Çakmaklı, C., \& Dijk, D. van ((2016). Getting the most out of macroeconomic information for predicting excess stock returns. International Journal of Forecasting, 32(3), 650-668.

https://doi.org/10.1016/j.ijforecast.2015.10.001

Canova, F., \& De Nicolo, G. (1995). Stock returns and the business cycle: A structural approach. European Economic Review, 39(5), 981-1017. https://doi.org/10.1016/0014-2921(95)00017-8

Carhart, M. M. (1997). On persistence in mutual fund performance. Journal of Finance, 52(1), 57-82. https://doi.org/10.1111/j.1540-6261.1997.tb03808.x

Chan, L. K. C., Karcesky, J., \& Lakonishok, J. (1998). The risk and return from factors. Journal of Financial and Quantitative Analysis, 33(2), 159-188. https://doi.org/10.2307/2331306

Chen, N. (1983). Some empirical tests of the theory of arbitrage pricing, The Journal of Finance, 38(5), 13931414. https://doi.org/10.1111/j.1540-6261.1983.tb03831.x

Chen, N., Roll, R., \& Ross, S. (1986). Economic forces and the stock market. Journal of Business, 59(3), 382-403. https://doi.org/10.1086/296344

Dzikevičius, A., \& Šarand, S. (2016). Establishing a set of macroeconomic factors explaining variation over time of performance in business sectors. Business: Theory and Practice, 17(2), 159-166. https://doi.org/10.3846/btp.2016.629

Errunza, V., \& Hogan, K. (1998). Macroeconomic determinants of European stock market volatility. European financial management, 4(3), 361-377. https://doi.org/10.1111/1468-036X.00071

Fama, E. F. (1990). Stock returns, expected returns, and real activity. Journal of Finance, 45(4), 1089-1108. https://doi.org/10.1111/j.1540-6261.1990.tb02428.x

Fama, E. F., \& French, K. R. (1993). Common risk factors in the returns on stocks and bonds. Journal of Financial Economics, 33(1), 3-56. https://doi.org/10.1016/0304-405X(93)90023-5

Fama, E. F., \& MacBeth, J. D. (1973). Risk, return, and equilibrium: Empirical tests. Journal of Political Economy, 81(3), 607-636. https://doi.org/10.1086/260061

Gnimassoun, B. (2015). The importance of the exchange rate regime in limiting current account imbalances in subSaharan African countries. Journal of International Money and Finance, 53, 36-74.

https://doi.org/10.1016/j.jimonfin.2014.12.012 


\section{INFLUENCE OF MACROECONOMIC FACTORS ON STOCK PRICES IN POLAND - CROSS SECTION AND TIME SERIES ANALYSIS}

Gurgul, H., \& Wójtowicz, T. (2014). The impact of US macroeconomic news on the Polish stock market. Central European Journal of Operations Research, 22(4), 795817. https://doi.org/10.1007/s10100-014-0343-x

Hanousek, J., \& Filer, R. K. (2000). The relationship between economic factors and equity markets in Central Europe. Economics of Transition, 8(3), 623-638. https://doi.org/10.1111/1468-0351.00058

Hendry, D. F., \& Krolzig, H. M. (2005). The properties of automatic GETS modelling. The Economic Journal, 115(502), 32-61. https://doi.org/10.1111/j.0013-0133.2005.00979.x

Horobet, A., \& Dumitrescu, S. (2009). On the causal relationships between monetary, financial and real macroeconomic variables: Evidence from central and Eastern Europe. Economic Computation and Economic Cybernetics Studies and Research, 43, 1-17.

Hsing, Y., \& Hsieh, W. (2012). Impacts of macroeconomic variables on the stock market index in Poland- new evidence. Journal of Business Economics and Management, 13(2), 334-343.

https://doi.org/10.3846/16111699.2011.620133

Jurksas, L., \& Paskevicius, A. (2017). The relationship between macroeconomy and asset prices: Long-run causality evidence from Lithuania. Organizations \& Markets in Emerging Economies, 8(1), 63-85.

Khan, M. N., Tantisantiwong, N., Fifield, S. G. M., \& Power, D. M. (2015). The relationship between South Asian stock returns and macroeconomic variables. Applied Economics, 47(13), 1298-1313. https://doi.org/10.1080/00036846.2014.995360

Ludvigson, S. C., \& Ng, S. (2007). The empirical risk-return relation: A factor analysis approach. Journal of Financial Economics, 83(1), 171-222.

https://doi.org/10.1016/j.jfineco.2005.12.002

Ludvigson, S. C., \& Ng, S. (2009). Macro factors in bond risk premia. Review of Financial Studies, 22(12), 50275067. https://doi.org/10.1093/rfs/hhp081

Maio, P., \& Philip, D. (2015). Macro variables and the components of stock returns. Journal of Empirical Finance, 33, 287-308.

https://doi.org/10.1016/j.jempfin.2015.03.004

Meluzin, T., Zinecker, M., \& Meluzinová, J. (2015). Macroeconomic and capital market determinants of initial public offerings: A Time-series analysis in the Polish capital market. Scientific papers of the University of Pardubice. Series D. Faculty of Economics \& Administration. 2015/34, 101-112.

Narayan, K. P., Narayan, S., \& Thuraisamy, K. S. (2014). Can institutions and macroeconomic factors predict stock returns in emerging markets?. Emerging Markets Review, 19, 77-95.

https://doi.org/10.1016/j.ememar.2014.04.005

Nell, K., \& Thirlwall, A. P. (2018). Explaining differences in the productivity of investment across countries in the context of "new growth theory. International Review of Applied Economics, 32(2), 163-194. https://doi.org/10.1080/02692171.2017.1333089

Panetta, F. (2002). The stability of the relation between the stock market and macroeconomic forces. Economic Notes, 31(3), 417-450. https://doi.org/10.1111/1468-0300.00093

Peiro, A. (2016). Stock prices and macroeconomic factors: Some European evidence. International Review of Economics \& Finance, 41, 287-294.

Pilinkus, D., \& Boguslauskas, V. (2009). The short-run relationship between stock market prices and macroeconomic variables in Lithuania: An application of the impulse response function, Engineering Economics, 65(5), 26-34.

Pražák, T., \& Stavárek D. (2017). The relationship between stock market development and macroeconomic fundamentals in the Visegrad Group. Comparative Economic Research, 20(3), 5-23. https://doi.org/10.1515/cer-2017-0017

Rapach, D. E., \& Wohar, M. E. (2006). Structural breaks and predictive regression models of aggregate US stock returns. Journal of Financial Econometrics, 4(2), 238274. https://doi.org/10.1093/jjfinec/nbj008

Rapach, D. E., Wohar, M. E., \& Rangvid, J. (2005). Macro variables and international stock return predictability. International Journal of Forecasting, 21(1), 137-166. https://doi.org/10.1016/j.ijforecast.2004.05.004

Roll, R., \& Ross, S. A. (1980). an empirical investigation of the arbitrage pricing theory. The Journal of Finance, 35(5), 1073-1103. https://doi.org/10.1111/j.1540-6261.1980.tb02197.x

Ross, S. (1976). The arbitrage theory of capital asset pricing. Journal of Economic Theory, 13(3), 341-360. https://doi.org/10.1016/0022-0531(76)90046-6

Rudzkis, R., \& Valkavicienė, R. (2014). Econometric models of the impact of macroeconomic processes on the stock market in the Baltic countries. Technological \& Economic Development of Economy, 20(4), 783-800. https://doi.org/10.3846/20294913.2014.949901

Samitas, A. G., \& Kenourgios, D. F. (2007). Macroeconomic factors' influence on 'new' European countries' stock returns: the case of four transition economies. International Journal of Financial Services Management, 2(1/2), 34-49. https://doi.org/10.1504/IJFSM.2007.011670

Schwert, G. W. (1990). Stock returns and real activity: A century of evidence. Journal of Finance, 45(4), 12371257.

https://doi.org/10.1111/j.1540-6261.1990.tb02434.x

Stock, J. H., \& Watson, M. W. (2002). Macroeconomic forecasting using diffusion indexes. Journal of Business \& Economic Statistics, 20(2), 147-162. https://doi.org/10.1198/073500102317351921

Tvaronavičiene, M., \& Michailova, J. (2006). Factors affecting securities prices: theoretical versus practical approach. Journal of Business Economics and Management, 7(4), 213-222. 